\title{
A controlled therapeutic trial in paucibacillary leprosy comparing a single dose of rifampicin with a single dose of rifampicin followed by one year of daily dapsone
}

\author{
S R PATTYN*, G GROENEN $\dagger$, L JANSSENS $\ddagger$, \\ L KUYKENS§, L B MPUTU† and the Collaborative Study \\ Group $\uparrow$ for the treatment of Leprosy in Zaire \\ * University of Antwerp and Institute of Tropical Medicine, \\ Antwerp, Belgium, $\dagger$ Bureau National de la lèpre Kinshasa, Zaire, \\ $\ddagger$ Museniene Hospital, Zaire, §Damien Foundation Kisangani
}

Accepted for publication 2 November 1990

\begin{abstract}
Summary The cure rates of two treatment regimens in PB leprosy were compared in a prospective randomized trial: treatment $U$ consisting of a single dose of rifampicin $40 \mathrm{mg} / \mathrm{K}$ bodyweight, and treatment $\mathrm{A}$ of rifampicin $1500 \mathrm{mg}$ in a single dose, followed by one year of daily dapsone $100 \mathrm{mg}$. In patients with a $\mathrm{BI}=0$, the cure rates evaluated on the basis of histopathology of skin biopsies, were identical for the two regimens but in patients with a $\mathrm{BI}=1$, cure and relapse rates were unacceptable. For this reason and particularly the need to separate patients on the basis of the BI in skin biopsies, the single dose regimen does not appear to be suited for wide-scale application.
\end{abstract}

\section{Introduction}

In previous studies several rifampicin (RMP) containing regimens have been shown to cure paucibacillary (PB) leprosy. ${ }^{1,2}$ The shortest regimen consisted of 6 daily doses of 600 mg RMP together with $100 \mathrm{mg}$ dapsone (DDS), ${ }^{2}$ while the regimen containing the smallest amount of RMP consisted of RMP $1500 \mathrm{mg}$ as a single dose followed by one year of DDS $100 \mathrm{mg}$ daily. ${ }^{1}$ Since in the latter regimen it may be expected that not all DDS tablets delivered to the patients were actually taken, ${ }^{3}$ the role of the associated DDS may be questioned.

In the mouse footpad model for experimental chemotherapy a single dose of $40 \mathrm{mg} / \mathrm{K}$ body weight of RMP prevents the multiplication of inocula of $5 \cdot 10^{3}$ to $10^{4}$ Mycobacterium

- Collaborative Study Group Zaire: N Bossaer, L Breugelmans, L Coussens, R De Raedt, E Nollet, L Olenga, J Verlinden. 
leprae. ${ }^{4,5}$ Since PB patients harbour not more than $10^{7} \mathrm{M}$. leprae ${ }^{6}$ a study on the activity of a single dose of RMP in PB leprosy may be justified.

A prospective controlled trial was therefore undertaken to compare the efficacy of a single dose of RMP, $40 \mathrm{mg} / \mathrm{K}$ body weight, with the previously evaluated regimen consisting of RMP $1500 \mathrm{mg}$, single dose, followed by one year of daily $100 \mathrm{mg}$ DDS.

\section{Patients and methods}

Leprosy patients were diagnosed after self-reporting or through referral. They were examined clinically and neurologically by experienced doctors or paramedical workers. Skin smears were taken from an earlobe and two skin lesions or two earlobes and the skin lesion when it was solitary. All patients were biopsied at the most active site and the biopsy, fixed in $10 \%$ formalin or Lowy's fixative, was sent to Antwerp, where sections were stained by the Trichrome-Fite-Farracco technique. ${ }^{7}$ Copies of all clinical files at the start and at follow-up examinations were also sent to Antwerp.

PB patients were defined as having clinical TT or BT leprosy with a bacteriological index (BI) of not more than 1 (Ridley scale), ${ }^{7}$ at any site examined and confirmed as TT or BT leprosy, BI $=0$ by histopathology.

Patients were randomly assigned to one of the following treatment regimens:

Treatment A (TrA) RMP 1500 mg single dose, supervised, followed by 1 year DDS 100 mg daily, unsupervised.

Treatment U (TrU) RMP $40 \mathrm{mg} / \mathrm{K}$ bodyweight, single dose. Patients were weighed and RMP administered as 300 and $150 \mathrm{mg}$ capsules, following a list of bodyweights, to reach or approach the $40 \mathrm{mg} / \mathrm{K}$ dose.

In the case of remote villages, randomization was done by village rather than on individual basis.

In the reference laboratory in Antwerp, and after treatment was started in the field, the patients were stratified according to $\mathrm{BI}(\mathrm{BI}=0$ and $\mathrm{BI}=1)$ and clinical symptoms: less than $3(-31)$ and 3 or more skin lesions $(+31)$.

Patients were followed clinically and by histopathology. A few patients had a skin biopsy at one year after the start of treatment, all had a biopsy at two years and thereafter at yearly intervals until no more signs of leprosy were found. A biopsy was also taken if aggravation was noted. The histopathology readings were done by an investigator who was not informed of the treatment regimen administered. The efficacy of the treatment regimens was evaluated by the proportion of patients cured and the relapse rate after cure, cure being defined as the absence of histopathological signs of leprosy, relapse as the reappearance of signs of leprosy in a biopsy after the initial histopathological cure.

For the analysis of results the life table technique was applied to take into account the withdrawal of some patients. For comparison of results the log-rank test was applied with significance at the 0.05 level. For comparison of relapse rates Fisher's exact test was applied.

\section{Results}

During 1983-85, 627 patients were taken into the study, 14 patients died from unrelated causes and $126(21 \%)$ patients were lost to follow-up (FU) within the first year af ter the start of treatment, leaving 487 for analysis, 247 on treatment A and 240 on treatment $\mathrm{U}$. 
Table 1. Number of patients, patient years of follow-up and cumulative percentages of cure in $\mathrm{PB}$ patients with $\mathrm{BI}=0$ and with less than 3 , or 3 or more skin lesions, after the start of treatment with regimens $\mathrm{A}$ and $\mathrm{U}$

\begin{tabular}{|c|c|c|c|c|}
\hline & \multicolumn{4}{|c|}{ Treatment regimens* } \\
\hline & \multicolumn{2}{|c|}{$\begin{array}{c}\text { A } \\
\text { (number of skin } \\
\text { lesions) }\end{array}$} & \multicolumn{2}{|c|}{$\begin{array}{c}\mathrm{U} \\
\text { (number of skin } \\
\text { lesions) }\end{array}$} \\
\hline & $<3$ & $\geqslant 3$ & $<3$ & $\geqslant 3$ \\
\hline & 87 & 137 & 98 & 125 \\
\hline & \multicolumn{4}{|c|}{ Patient years of follow-up } \\
\hline & 355 & 547 & 381 & 513 \\
\hline $\begin{array}{l}\text { Months after start } \\
\text { of treatment }\end{array}$ & \multicolumn{4}{|c|}{$\begin{array}{l}\text { Cumulative percentages of } \\
\text { histopathological cures }\end{array}$} \\
\hline 12 & 17 & 12 & 13 & 8 \\
\hline 24 & 64 & 67 & 53 & 54 \\
\hline 36 & 81 & 78 & 85 & 67 \\
\hline 48 & 94 & 85 & 96 & 89 \\
\hline 60 & 94 & 92 & 96 & 92 \\
\hline
\end{tabular}

* See Patients and methods.

The results were analysed separately for patients with a $\mathrm{BI}=1$ and those with a $\mathrm{BI}=0$, and among the latter, patients with less than 3 or with 3 or more skin lesions.

The cumulative, yearly percentages of cure after the start of treatment for patients with $\mathrm{a} \mathrm{BI}=0$ are presented in Table 1 . There are no statistically significant differences between patients with less than 3 or with 3 or more skin lesions in either regimen or between the two regimens, although the patients with a small number of lesions tend to evolve somewhat more rapidly, particularly in regimen $\mathrm{U}$ at 36 months.

Table 2 shows the results in patients with a $\mathrm{BI}=1$. For this group of patients no stratification for the number of skin lesions was made because of the small numbers, the majority having more than 3 skin lesions: only one patient in regimen $\mathrm{A}$ and 2 patients in regimen $U$ had less than 3 skin lesions. The cumulative cure rate for the patients treated with a single dose of RMP reaches only $76 \%$ at 48 months, however none of the patients not cured up to that time were seen at 60 months. The cumulative percentages of cure at any interval are not significantly different between the two regimens, nor between the patients with either $\mathrm{IB}=0$ or $\mathrm{BI}=1$. However, the absence of a significant difference, between the patients with a $\mathrm{BI}=1$ and treated with a single dose of RMP and all the other groups results from the small number of patients in the $\mathrm{U}$ group with a $\mathrm{BI}=1$.

Reappearance of a histological leprosy lesion in follow-up biopsies were observed in 26 cases. Two cases in the group $\mathrm{BI}=0$, treatment $\mathrm{A}$ with more than 3 skin lesions, were accompanied by definite clinical signs of reversal reaction: thickening of the upper lip region, or lagophthalmos with a thickened cervical nerve, appearing respectively at 37 
Table 2. Number of patients, patient years of follow-up and cumulative percentages of histological cures in PB leprosy patients with $\mathrm{BI}=1$ after the start of treatment with regimens A and $\mathrm{U}$

\begin{tabular}{|c|c|c|}
\hline & \multicolumn{2}{|c|}{ Treatment regimens* } \\
\hline & $\begin{array}{c}\mathrm{A} \\
\mathrm{n}=23 \dagger\end{array}$ & $\begin{array}{c}\mathrm{U} \\
\mathrm{n}=17 \ddagger\end{array}$ \\
\hline & \multicolumn{2}{|c|}{ Patient years of follow-up } \\
\hline & 87 & 69 \\
\hline $\begin{array}{l}\text { Months af ter start } \\
\text { of treatment }\end{array}$ & & $\begin{array}{l}\text { Cumulative percentages of } \\
\text { histopathological cures }\end{array}$ \\
\hline 12 & 22 & 24 \\
\hline 24 & 56 & 53 \\
\hline 36 & 69 & 65 \\
\hline 48 & 81 & 76 \\
\hline 60 & 90 & 76 \\
\hline
\end{tabular}

* See Patients and methods.

$\dagger$ Of whom one patient with less than 3 skin lesions.

$\ddagger$ Of whom two patients with less than 3 skin lesions.

and 39 months after the start of treatment. In 3 other cases the histological lesions resolved spontaneously in the next biopsy (all 3 in the $\mathrm{BI}=0$ group, with more than 3 skin lesions, 2 cases with treatment $A$ and 1 case with treatment $U$ ). These 5 cases were interpreted as reversal reactions leaving a total of 21 relapses.

Table 3 presents for each patient group the number of relapses, the incidence per 100

Table 3. Number and incidence of relapses and delay of their appearance in the different patient groups

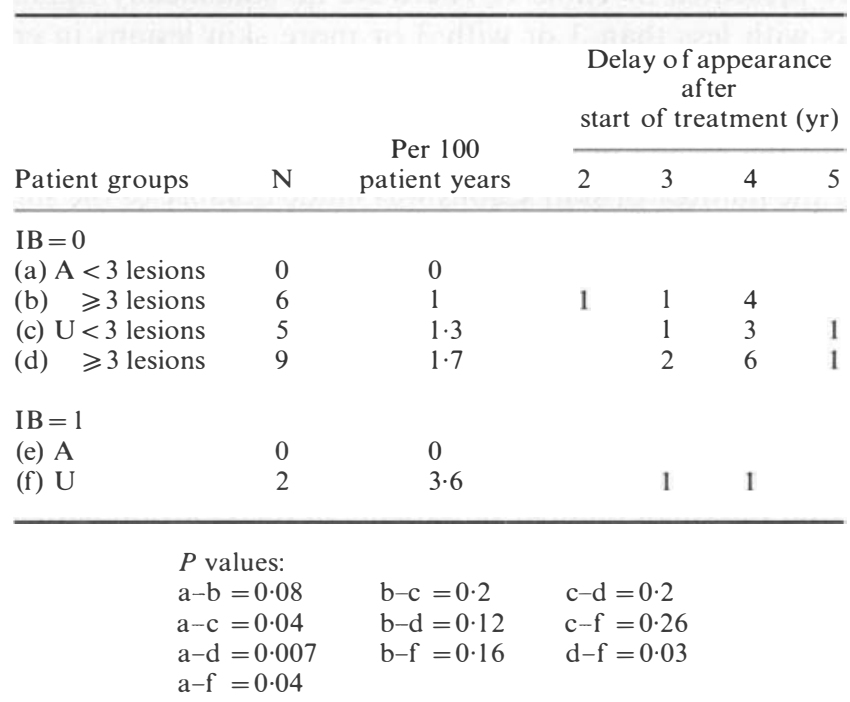


patients years of follow-up and the delay of appearance after the start of therapy. There is a gradual increase of relapse rates from group (a) $(B I=0$, less than 3 skin lesions, treatment $\mathrm{A})$ to (f) $(\mathrm{BI}=1$, more than 3 skin lesions, treatment $\mathrm{U})$ with the exception of group (e). The only statistical significant differences are between patients in treatment group $\mathrm{A}$ with $\mathrm{BI}=0$ and less than 3 skin lesions and all the patients in treatment groups $\mathrm{U}$. Relapses appear 3-5 years af ter the start of treatment, with a majority, $66 \cdot 6 \%$, at 4 years.

The regimens, particularly the single dose RMP regimen, were well tolerated, no sideeffects were observed. There were no significant differences between regimens $\mathrm{A}$ and $\mathrm{U}$ with respect to increase of mutilations and hypertrophied nerves between the start of treatment and the last follow-up examination (data not shown).

\section{Discussion}

Based on calculations made by Shepard ${ }^{8}$ a $\mathrm{BI}=1$ corresponds to a total bacterial load of $10^{7}$ Mycobacterium leprae and a $\mathrm{BI}=0$ to $10^{6}$ or less. Since a single dose of RMP kills at least $5 \cdot 10^{3} M$. leprae, ${ }^{8}$ it may be expected that the infecting $M$. leprae in some PB patients will be eradicated by a single dose of the drug, while in others they will be reduced to very low numbers, of the order of $10^{2}-10^{4}$, which may be expected to be eliminated by the immune mechanisms of the patients, as is the rule in other infectious diseases treated with antibiotics. We therefore compared a single dose RMP treatment with regimen A, known from a previous study to give excellent results and particularly suited for many situations in developing countries. ${ }^{1}$

Single dose treatment of infectious diseases are presently known for giardiasis, gonorrhoea, ${ }^{9}$ vaginal trichomoniasis ${ }^{10}$ and candidiasis, ${ }^{11}$ bacterial vaginosis, ${ }^{12}$ primary syphilis, ${ }^{13}$ lower urinary tract infection, ${ }^{14}$ meningococcal meningitis, ${ }^{15}$ and typhus. ${ }^{16}$ These treatments are based on the use of either long acting drugs (benzathine penicillin for syphilis, ceftriaxone for gonorrhoea, long acting chloramphenicol for meningococcal meningitis, doxycycline for typhus) or the administration of a drug in a high dose (ampicillin for gonorrhoea, metronidazole for trichomoniasis or bacterial vaginosis, drugs active against urinary pathogens). The advantages of this type of treatment are low cost, fewer side-effects and maximal supervision. Since most leprosy cases in the world belong to the PB group, the advantages of a single dose treatment are obvious.

In the present study, among the patients with a $\mathrm{BI}=0$, the cure rate after a single high dose of RMP is identical with that after regimen A, although there is a slight tendency for some slower progress at 36 months after the start of treatment. However, for PB patients with a $\mathrm{BI}=1$ the cure rate of $76 \%$ obtained after treatment $\mathrm{U}$ is unacceptable. The shortcoming of treatment $\mathrm{U}$ is further illustrated by the rising incidence of the relapse rate from 1.3 to $1.7 \%$ among patients with a $\mathrm{BI}=0$ to $3.6 \%$ among patients with a $\mathrm{BI}=1$. The only statistically significant differences between the different regimens are between $U$ and A (Table 3 bottom).

The single high dose RMP treatment presented here has too many shortcomings to be used on a wide scale.

The weight adjusted dosage is too cumbersome, single dose therapy could only be practical if a less stringent dosage could be administered. The necessity for a high dose, which was derived from experiments in mice, ${ }^{8}$ could be questioned, although the pharmacokinetics of RMP is more favourable in mouse than in man. ${ }^{17}$ 
But the most important observation is that patients with a $\mathrm{BI}=1$ should be excluded from treatment $\mathrm{U}$. In the present study, the distinction between $\mathrm{BI}=0$ and $\mathrm{BI}=1$ was always made by histopathology, when a bacillus was observed in a nerve twig. This procedure is inapplicable in control programmes.

In this study we were once more confronted with the unsolved problem of the distinction between relapse and reversal reaction in PB leprosy, although taking into consideration the clinical data, 5/26 histopathological relapses were compatible with reversal reactions, but it seems that the maximum incidence of relapses is situated at 3-4 years after the start of treatment.

\section{Acknowledgments}

The Leprosy Laboratory of the Institute of Tropical Medecine Antwerpen, received financial support from the Damien Foundation Brussels, Belgium, the Nationale Loterij and the European Economic Community.

\section{References}

1 Pattyn SR, Groenen G, Bourland J, Grillone S, Janssens L. A controlled therapeutic trial in paucibacillary leprosy comparing a single dose of rifampicin followed by one year of daily dapsone with 10 weekly doses of rifampicin. Lepr Rev, 1987; 58: 349-58.

2 Pattyn SR, Husser JA, Baquillon G, Maiga M, Jamet P. Evaluation of five treatment regimens, using either dapsone monotherapy or several doses of rifampicin in the treatment of paucibillary leprosy. Lepr Rev, 1990, 61, 151-6.

3 Ellard GA, Gammon PT, Helmy HS, Rees RJW. Urine tests to monitor the self administration of dapsone by leprosy patients. Amer J Trop Med Hyg, 1974; 23: 464-70.

${ }^{4}$ Shepard CC, Levy L, Fasal P. Rifampicin and Mycobacterium leprae. Int J Lepr, 1972; 44: 459-60.

${ }^{5}$ Pattyn SR. A comparison of the bactericidal activity of a series of rifamycins against Mycobacterium leprae. Drug Res, 1982; 32: 15-17.

${ }^{6}$ Shepard CC. Recent developments in the chemotherapy and chemoprophylaxis of leprosy. Leprologia (Argentina), 1974; 19: 230-4.

7 Pattyn SR, Dockx P, Cap JA. La lèpre. Masson Ed. Paris 1981.

8 Shepard CC, Levy L, Fasal P. Rapid bactericidal effect of rifampicin on Mycobacterium leprae. Am J Trop Med Hyg, 1972; 21: 446-9.

9 Morbidity and Mortality Weekly Report, (CDC, Atlanta, USA), 1989; S8, p 22.

10 Dijkers JR. Single dose metronidazole for trichomonal vaginitis. New Engl J Med, 1975; 293: $23-4$.

11 Morbidity and Mortality Weekly Report (CDC, Atlanta, USA) 1989; 38, S8, p 35.

12 Swedberg J, Steiner JF, Deiss F, Steiner S, Driggers DA. Comparison of single dose versus one week course of metronidazole for symptomatic bacterial vaginosis. JAMA, 1985; 254: 1046-9.

13 Morbidity and Mortality Weekly Report (CDC, Atlanta, USA) 1989; 38, S8, p. 7.

${ }^{14}$ Kunin CM. Duration of treatment of urinary tract infections. Am J Med, 71: 849-54.

15 Wali SS, MacFarlane JT, Weir WRC, Cleland PG, Ball PAJ, Hassan-King M, Whittle HC, Greenwood BM. Single injection treatment of meningococcal meningitis. 2. Long-acting chloramfenicol. Trans RS Trop Med Hyg, 1979; 73: 698-702.

16 Huys J, Freyens P, Kayihigi, Van Den Berghe G. Treatment of epidemic typhus. A comparative study of chloramfenicol, trimethoprimsulphamethoxazole and doxycycline. Trans $R$ S Trop Med Hyg, 1973; 67: 71821 .

17 Grosset JH. Pharmacokinetics in drug screening. Int J Lepr, 1987; 44 (suppl) 852-9. 
Un essai thérapeutique controlé de la lèpre paucibacillaire - comparaison de la dose unique de rif ampicine et dose unique de rif ampicine suivie d'une dose quotidienne de 100 mg de Dapsone pendant un an

\author{
S R Pattyn, G Groenen, L Janssens, L Kuykens, L B Mputu et \\ The Collaborative Study Group
}

Sommaire Les taux de guérison de deux régimes pour le traitement de la lèpre paucibacillaire (PB) ont été comparés dans un essai prospectif aléatoire: le premier traitement (U) comprenait une dose unique de rif ampicine de $40 \mathrm{mg}$ par kilo de poids, le deuxième (A), une dose unique de $1500 \mathrm{mg}$ de rifampicine suivie d'une dose quotidienne de $100 \mathrm{mg}$ de Dapsone pendant un an. Les taux de guérison évalués à partir de l'histopathologie des biopsies de peau ont été pareils pour les deux régimes pour des patients avec un $\mathrm{BI}=0$, mais pour ceux dont le $\mathrm{BI}=1$, les taux de guérison et de rechute ont été inadmissibles. Pour cette raison et, en particulier, en vue de la necessité de séparer les patients par rapport a leur BI dans les biopsies de peau, le régime à dose unique ne semble pas être satisfaisant pour l'usage sur une grande échelle.

\title{
Un ensayo terapéutico limitado sobre la lepra paucibacilar comparando los efectos de una dosis única de rifampicina con los de una dosis única de rifampicina seguida de una dosis diaria de dapsona durante un año
}

\author{
S R Pattyn, G Groenen, L Janssens, L Kuykens, L B Mputu y \\ The Collaborative Study Group
}

Resumen Se compararon los índices de recuperación completa de dos regímenes de tratamiento para la lepra paucibacilar (PB) por medio de una prueba anticipada aleatorizada: el primer tratamiento (U), una dosis única de rifampicina de $40 \mathrm{mg}$ por kilo de peso y el segundo (A), una dosis única de $1500 \mathrm{mg}$ de rifampicina, seguida de una dosis diaria de $100 \mathrm{mg}$ de dapsona durante un año. En el caso de los pacientes con un $\mathrm{BI}=0$, los índices de recuperación calculados a partir de la histopatología de biopsias cutáneas resultaron ser idénticos para los dos regímenes. En cambio, aquellos pacientes con $\mathrm{BI}=1$, mostraron índices de recuperación y de recaída inadmisibles. Por esta razón, y dada la necesidad de separar a los pacientes según el BI obtenido en las biopsias cutáneas, el régimen de dosis única no parece ser adecuado para la utilización a gran escala. 